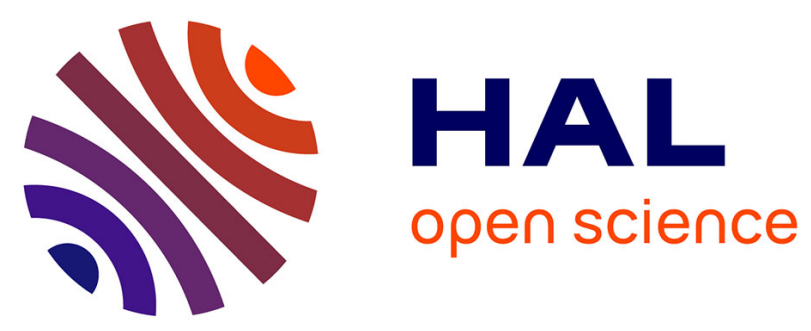

\title{
Pyrolysis of n- octane at very low concentration and low temperature
}

N. Razafinarivo, R. Bounaceur, V. Burklé-Vitzthum, F. Lannuzel, R. Michels, G. Scacchi, P.M. M Marquaire

\section{> To cite this version:}

N. Razafinarivo, R. Bounaceur, V. Burklé-Vitzthum, F. Lannuzel, R. Michels, et al.. Pyrolysis of noctane at very low concentration and low temperature. Journal of Analytical and Applied Pyrolysis, 2016, 117, pp.282-289. 10.1016/j.jaap.2015.11.004 . hal-02930918

\section{HAL Id: hal-02930918 \\ https://hal.univ-lorraine.fr/hal-02930918}

Submitted on 3 Feb 2022

HAL is a multi-disciplinary open access archive for the deposit and dissemination of scientific research documents, whether they are published or not. The documents may come from teaching and research institutions in France or abroad, or from public or private research centers.
L'archive ouverte pluridisciplinaire HAL, est destinée au dépôt et à la diffusion de documents scientifiques de niveau recherche, publiés ou non, émanant des établissements d'enseignement et de recherche français ou étrangers, des laboratoires publics ou privés.

\section{(1) (1) $\$$}

Distributed under a Creative Commons Attribution - NonCommercial - NoDerivatives| 4.0 
N. Razafinarivo ${ }^{\mathrm{a}, \mathrm{b}}$, R. Bounaceur ${ }^{\mathrm{a}}$, V. Burklé-Vitzthum ${ }^{\mathrm{a}}, \mathrm{F}$. Lannuzel $^{\mathrm{a}, \mathrm{b}}$, R. Michels ${ }^{\mathrm{b}}$, G. Scacchi ${ }^{\text {a }}$ P.M. Marquaire ${ }^{\text {a }}$

6

${ }^{a}$ Laboratoire Réactions et Génie des Procédés, CNRS-UMR 7274, Université de Lorraine, ENSIC, 1 rue Grandville, BP 20451, F-54001 NANCY Cedex, France 9 Université de Lorraine, BP 70239, F-54501 Vandœuvre lès Nancy, France

Hydrocarbon pyrolysis concerns many different fields (petroleum geochemistry, refinery, fuel thermal stability, pyrocarbon deposition, etc.). It is therefore studied in a wide variety of temperature-pressure experimental conditions, which strongly affect the chemistry of hydrocarbons cracking.

An experimental study of the pyrolysis of $n$-octane has been performed at very low reactant concentration (1 mbar diluted in inert gas - total pressure 1500 mbar - molar fraction $0.07 \%$ ) in a closed reactor, at temperatures ranging between $350^{\circ} \mathrm{C}$ and $450^{\circ} \mathrm{C}$, and reaction time from $1 \mathrm{~h}$ to 70 h. The major products of the reaction are 1-alkenes $\left(\mathrm{C}_{2} \mathrm{H}_{4}\right.$ to $\left.\mathrm{C}_{7} \mathrm{H}_{14}\right)$, methane and ethane; other alkanes $\left(\mathrm{C}_{3} \mathrm{H}_{8}\right.$ to $\left.\mathrm{C}_{6} \mathrm{H}_{14}\right)$ are minor products. At $450^{\circ} \mathrm{C}$ and $4 \mathrm{~h}$, the conversion is close to $9 \%$ and we observe, in terms of molar fractions:

$$
\mathrm{C}_{2} \mathrm{H}_{4}>\mathrm{C}_{3} \mathrm{H}_{6} \approx \mathrm{CH}_{4}>\mathrm{C}_{4} \mathrm{H}_{8}>\mathrm{C}_{5} \mathrm{H}_{10}>\mathrm{C}_{6} \mathrm{H}_{12} \approx \mathrm{C}_{2} \mathrm{H}_{6}>\mathrm{C}_{7} \mathrm{H}_{14}
$$

These experimental results are very different from those of the thermal decomposition of $n$ 26 alkanes at the same low temperature but at high pressure. In particular, the cracking 
(except methane and ethane) are in very low quantities. This can be explained by the very low concentration of reactant which limits the bimolecular reactions. In our conditions, the radicals decompose several times by beta-scissions of $\mathrm{C}-\mathrm{C}$ bonds when it is possible (unimolecular reaction), rather than react by $\mathrm{H}$-transfers (metathesis) with the reactant (bimolecular reaction) which produce alkanes. A detailed free radical mechanism (184 reactions, 16 molecules and 18 radicals - mechanism available as Supplementary Material) allows modelling the experimental results.

\section{Keywords}

Pyrolysis, $n$-Octane, Thermal decomposition, High dilution of reactant, Kinetic modelling.

\section{Introduction}

Thermal chemistry of hydrocarbons during pyrolysis is important in many research fields as petroleum geochemistry [1-3], refining of crude oils, cracking of hydrocarbons to produce light olefins [4-7], thermal decomposition of endothermic jet fuels [8-10], conversion of coal and biomass to liquid fuels [11-14], depolymerization and recycling of synthetic polymers [15-17], pyrocarbon deposition for the elaboration of $\mathrm{C} / \mathrm{C}$ composite materials [18-20], etc. The reaction conditions considered cover a very wide range of time and temperature, from $150^{\circ} \mathrm{C}$ during several millions of years in geochemistry studies, to $900^{\circ} \mathrm{C}$ for a few milliseconds or seconds during ethane/propane steam-cracking for instance. The pressure (and consequently the concentration of hydrocarbons) can also vary in a very large domain, from some millibars to 1000 bar. This diversity of pyrolysis conditions is illustrated in different reviews (e.g. [21, 22]). Free-radical reaction pathways are considered as the dominant mechanisms for pyrolysis reactions of organic materials (e.g. [22-24]). The pyrolysis chemistry of the same reactant (and the main products formed) can largely be modified according to the conditions of the reaction (temperature, pressure and time). The knowledge of the thermal reaction mechanism and the rate 
of the different pathways provide means to better understand hydrocarbon pyrolysis as well as valuable information for kinetic modelling.

The study of the pyrolysis of $n$-alkanes is simpler than that of other hydrocarbons or organic components. It is rather well known because it has been widely studied for a long time (e.g. [2434]). Except for methane, the pyrolysis of alkanes consists of free-radical chain reactions. The chemistry is similar whatever the size of the alkane, yet the number of products formed (and the size of the reaction mechanism) increases with the number of carbon atoms of the molecule. At low and usual pressure (0.1-10 bar), the pyrolysis of an alkane produces 1-alkenes and smaller alkanes or hydrogen by cracking reaction. For example, the pyrolysis of propane leads to two main stoichiometric equations:

$$
\begin{aligned}
& \mathrm{C}_{3} \mathrm{H}_{8}=\mathrm{C}_{2} \mathrm{H}_{4}+\mathrm{CH}_{4} \\
& \mathrm{C}_{3} \mathrm{H}_{8}=\mathrm{C}_{3} \mathrm{H}_{6}+\mathrm{H}_{2}
\end{aligned}
$$

This reaction is used for olefin production by steam-cracking for instance.

In petroleum geochemistry, at high pressure (P>100bar) and low temperature $\left(200<\mathrm{T}<500^{\circ} \mathrm{C}\right)$, several alkanes were chosen as model molecules of the alkane family in oils. For instance, $n$ hexane was chosen [28-29], as well as $n$-pentacosane [35], $n$-hexadecane [36-38] and $n$-octane [39]. In HP-LT (High Pressure-Low Temperature) conditions, the pyrolysis of alkanes is a long chain radical-reaction with two major types of propagation chains: a cracking chain and an alkylation one.

In HP-LT conditions, the detailed kinetic model of alkane pyrolysis was already investigated by several authors (e.g. [24, 29, 40-42]). Therefore, only the major aspects will be recalled here. The pyrolysis of an alkane (here called « $\mu \mathrm{H} »[40])$ can be schematized by the following freeradical cracking mechanism where $\mu \cdot$ and $\beta$ are free radicals.

Each cracking propagation chain includes two steps: a decomposition reaction by $\beta$-scission and an H-transfer reaction: 
Alkylation chain:

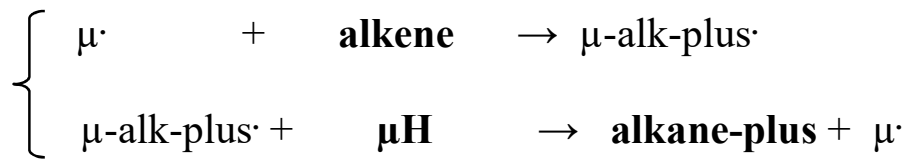
$\mu \mathrm{H}$.

The alkylation propagation chains include two types of free radical reactions: additions of $\mu$. radicals to alkenes and $\mathrm{H}$-transfers:

$$
\mu \mathrm{H}=\text { alkane-minus }+ \text { alkene }
$$

where $\beta$. is a radical lighter than $\mu$, and « alkane-minus » is an alkane lighter than the reactant

It leads to the alkylation stoichiometric equation (II):

$$
\text { alkene }+\mu \mathrm{H}=\text { alkane-plus }
$$

where $\mu$-alk-plus' is a radical heavier than $\mu$, and «alkane-plus » is the corresponding alkane which is heavier than the reactant $\mu \mathrm{H}$.

At low temperature, the addition reactions are fast and the alkylation chains become important, because the activation energy of the additions is particularly low (about $25-34 \mathrm{~kJ} / \mathrm{mol}$ ). So the alkenes become minor products and the global (I + II) stoichiometric equation is:

$$
\mu \mathrm{H}+\boldsymbol{\mu H}=\text { alkane-minus }+ \text { alkane-plus }
$$

Isomerization reactions also play an important role in product distribution. They can be unimolecular (1,4 and 1,5 $\mathrm{H}$ shift isomerization) and bimolecular by $\mathrm{H}$-transfers between the reactant $\mu \mathrm{H}$ and one of its associated radicals $\mu_{\mathrm{i}}$ leading to another isomer radical $\mu_{\mathrm{j}}$ :

$$
\begin{aligned}
& \mu_{\mathrm{i}^{*}} \rightleftarrows \mu_{\mathrm{j}} \\
& \mu_{\mathrm{i}}+\mu \mathrm{H} \rightleftarrows \mu_{\mathrm{j}^{*}+\mu \mathrm{H}}
\end{aligned}
$$


106 We already studied and modelled the pyrolysis at high pressure (700 bar) and low temperature $107\left(300-400^{\circ} \mathrm{C}\right)$ of $n$-octane [39] and hexadecane [36-38]. The mechanisms described above lead to 108 modelling results consistent with the experimental ones and they are therefore considered as 109 sufficiently complete (meaning that no major reaction was missing).

110 For $n$-octane pyrolysis, there are 4 radicals $\mu_{\mathrm{i}}{ }^{\circ}(\mathrm{i}=1$ to 4 , Figure 1$)$ and 6 stoichiometric 111 equations. The major products are: - 6 "alkane-minus": $\mathrm{CH}_{4}$ to $\mathrm{C}_{6} \mathrm{H}_{14}$ - 6 "alkane-plus": $\quad \mathrm{C}_{10} \mathrm{H}_{22}$ to $\mathrm{C}_{15} \mathrm{H}_{32}$

114 and the alkenes are minor products : $\mathrm{C}_{2} \mathrm{H}_{4}$ to $\mathrm{C}_{7} \mathrm{H}_{14}$

115 The objective of this work is to provide background information on the radical reactions 116 occurring during the pyrolysis of $n$-octane at very low reactant concentration ( 1 mbar diluted in 117 inert gas - total pressure 1500 mbar - molar fraction $0.07 \%$ ). It is to be noted that the pressure 118 dependence of rate constant ("fall-off") [e.g. 23] is not studied here, because the total pressure is 119 always above 1 bar. These results are used for constructing a kinetic model. Conditions of low 120 reactant concentration $(\leq 10$ mbar of partial pressure) can be found in various processes or 121 natural conditions: unburned gas and pollutants in fumes [43, 44], low pressure plasmas, 122 chemical vapor deposition (CVD) [45-48], very low pressure pyrolysis (VLPP) studies [25-28], 123 atmospheric chemistry (earth or other planets) [49, 50], etc.

\section{Experimental technique}

126 The experimental pyrolysis study of $n$-octane has been performed in gas phase at very low

127 reactant pressure $(1$ mbar) in a closed reactor $(1 \mathrm{~L})$ made of Pyrex. The $n$-octane is diluted in 128 argon and the total pressure is close to 1500 mbar. Special care was taken to avoid oxygen traces. 129 The temperatures range between $350^{\circ} \mathrm{C}$ and $450^{\circ} \mathrm{C}$ and the reaction time from $1 \mathrm{~h}$ to $70 \mathrm{~h}$. The 130 analysis was performed by two on-line gas chromatographs. Figure 2 shows the flow sheet of the 131 experimental apparatus. 
132 The experimental setup is connected to a vacuum pump $\left(<10^{-3} \mathrm{mbar}\right)$. The gases are introduced

133 in the reactor via a round-bottomed flask $(2 \mathrm{~L})$ which allows the mixing of the reactant and the 134 inert gas (argon). The liquid reactant (n-octane) is introduced by a syringe through a double 135 septum, protected from the air by a flow of argon. The amount of reactant is very small (10-50 $136 \mu \mathrm{L})$, as to ensure that it is totally vaporized in the mixer which is under vacuum $\left(<10^{-3}\right.$ mbar $)$. 137 Inert gas is introduced by a central injector equipped with 4 nozzles in order to homogenize the 138 mixture. The total pressure in the mixer reaches 2-3 bar, which allows the expansion of the gas 139 toward the reactor in a second step.

140 The main three steps of an experiment are:

141 - pumping of all experimental setup and heating of the empty reactor,

142 - mixing of the reactant-argon mixture in the mixer and waiting for the homogenization 143 during $10 \mathrm{~min}$,

144 - expansion of the gases toward the reactor and beginning of the thermal reaction.

145 During the same experiment, an aliquot fraction is removed at different reaction times from the 146 reactor by expansion toward the heated analysis line. The amount of the aliquot fraction is very 147 small and controlled by the pressure in the reactor (maximum drop of pressure $=20$ mbar). The 148 pressure drops are small in regards to the total pressure in the reactor (1500 mbar). Therefore, 149 several aliquot fractions can be removed from the reactor without disturbing the reaction.

150 The analysis of the reactant and the products is performed by two online Gas Chromatographs. 151 The chromatograph HEWLETT-PACKARD HP 6850 is equipped with a FID and a semi152 capillary column (GS-Alumina, length $30 \mathrm{~m}$, diameter $0.53 \mathrm{~mm}$ ). The temperature program of 153 the oven is as follows: the initial temperature is set at $40^{\circ} \mathrm{C}$ during $10 \mathrm{~min}$, then a heating rate of $15410{ }^{\circ} \mathrm{C} / \mathrm{min}$ is applied up to $190^{\circ} \mathrm{C}$, and the final temperature is kept at $190^{\circ} \mathrm{C}$ during $20 \mathrm{~min}$. This 155 allows the analysis of the light alkanes and alkenes (from $\mathrm{C}_{1}$ to $\mathrm{C}_{8}$ ). In this setup, hydrogen 156 cannot be measured.

157 The chromatograph SHIMADZU GC 17 is equipped with a FID and a packed column (Alltech, 
158 length $3.6 \mathrm{~m}$, stationary phase: $35 \% \mathrm{BCEF}-10 \% \mathrm{OV} 101$ ), which works isothermally at $50^{\circ} \mathrm{C}$.

159 It is particularly well adapted to the analysis of the heavy alkanes from $\mathrm{C}_{9}$ to $\mathrm{C}_{15}$, but none of 160 them was detected in the entire study. The GC calibrations were performed by using several 161 standard mixtures.

162 All data presented in this paper were generally verified by three or four sets of GC data. The 163 repeatability for the molar fractions is usually less than $5 \%$ for the major products. The carbon

164 balance is typically $1 \pm 0.05$ and the $\mathrm{C} / \mathrm{H}$ ratio remains quite constant (between 0.40 and 0.44 at $165400^{\circ} \mathrm{C}$ and between 0.44 and 0.47 at $450^{\circ} \mathrm{C}$ ).

\section{3. Experimental results}

167 The major products obtained are methane, ethane and 1-alkenes $\left(\mathrm{C}_{2} \mathrm{H}_{4}\right.$ to $\left.\mathrm{C}_{7} \mathrm{H}_{14}\right)$. Figures 3 show 168 the evolution of conversion versus reaction time at different temperatures.

169 At $450^{\circ} \mathrm{C}$ and $4 \mathrm{~h}$, the $n$-octane conversion is greater than $8 \%$ and the three main reaction products are ethylene, propene and methane, with molar fractions ranging in the following order:

$$
\mathrm{C}_{2} \mathrm{H}_{4}>\mathrm{C}_{3} \mathrm{H}_{6} \cong \mathrm{CH}_{4}
$$

172 followed by higher alkenes and ethane:

$$
\mathrm{C}_{4} \mathrm{H}_{8}>\mathrm{C}_{5} \mathrm{H}_{10}>\mathrm{C}_{6} \mathrm{H}_{12} \cong \mathrm{C}_{2} \mathrm{H}_{6}>\mathrm{C}_{7} \mathrm{H}_{14}
$$

174 The minor products observed are alkanes from $\mathrm{C}_{3} \mathrm{H}_{8}$ to $\mathrm{C}_{7} \mathrm{H}_{16}$.

175 The evolution of products versus reaction time will be detailed beneath in section 5 dedicated to

176 the modeling. Figure 4 represents the global evolution of alkanes-minus and alkenes that are the

177 two families of products.

178 It should be noted that these experimental results are very different from the thermal

179 decomposition of $n$-alkanes at the same low temperature but at high pressure [39]. In particular,

180 the cracking stoichiometric equations (for example: $\mathrm{C}_{8} \mathrm{H}_{18}=\mathrm{C}_{2} \mathrm{H}_{4}+\mathrm{C}_{6} \mathrm{H}_{14}$ ) are not observed

181 since $\mathrm{C}_{3}{ }^{+}$alkanes are in very low quantities and the alkylation stoichiometric equation (for 182 example: $\left.\mathrm{C}_{8} \mathrm{H}_{18}+\mathrm{C}_{2} \mathrm{H}_{4}=\mathrm{C}_{10} \mathrm{H}_{22}\right)$ are negligible: alkenes are important and alkanes-plus $\left(\mathrm{C}_{8}^{+}\right)$are 
183 not detected. The experimental results at $450^{\circ} \mathrm{C}$ are given in Table 1 and the details as

184 Supplementary Materials.

185

\section{Discussion: kinetic mechanism of $\boldsymbol{n}$-octane pyrolysis at very low concentration}

187

In comparison with the study of the pyrolysis of $n$-octane at 700 bar [39], the range of temperature is the same $\left(350-450^{\circ} \mathrm{C}\right)$, but the reactant partial pressure $(1 \mathrm{mbar})$ is very different, the initial concentration of reactant being lower by more than a factor of $10^{5}$. The very low concentration of reactant (called $\mu \mathrm{H}$ ) minimizes the importance of the bimolecular reactions in the mechanism, in particular the H-transfer in the cracking propagation chain:

$$
\left\{\begin{array}{llll}
\mu \cdot & \rightarrow & \text { alkene }+\beta \cdot & \text { (decomposition by } \beta \text {-scission) } \\
\beta \cdot+\mu \mathrm{H} \rightarrow & \beta \mathrm{H}+\mu \cdot & \text { (H-transfer) }
\end{array}\right.
$$

In our low concentration conditions, the radicals are decomposed by $\beta$-scission of $\mathrm{C}-\mathrm{C}$ bonds as much as possible (unimolecular reaction), rather than reacting by $\mathrm{H}$-transfer with the reactant (bimolecular reaction, which produces an alkane). The methyl and ethyl radicals cannot be decomposed by $\beta$-scission of $\mathrm{C}$-C bonds, so they react by $\mathrm{H}$-transfer with the reactant and produce methane or ethane and $\mu \cdot$ which is the chain carrier radical. At low temperature and low pressure, the cracking propagation chain becomes:

$$
\mu \cdot \quad \rightarrow \quad \text { alkene- } 1+\beta
$$$$
\beta \cdot \quad \text { alkene- } 2+\beta_{i} \cdot
$$$$
\beta_{\mathrm{i}^{*}} \rightarrow \text { alkene- } 3+\beta_{\mathrm{j}^{*}} \text { and when } \beta_{\mathrm{j}^{*}}=\mathrm{CH}_{3} \cdot \text { or } \mathrm{C}_{2} \mathrm{H}_{5}{ }^{*},
$$$$
\mathrm{CH}_{3} \cdot \text { or } \mathrm{C}_{2} \mathrm{H}_{5} \cdot \mu \mathrm{H} \rightarrow \mathrm{CH}_{4} \text { or } \mathrm{C}_{2} \mathrm{H}_{6}+\mu \cdot
$$

For the $n$-octane pyrolysis, there are $4 \mu_{\mathrm{i}}$ radicals (Figure 1), which lead to 4 cracking 
propagation chains and 4 stoichiometric equations.

210 From $\mu_{1}$ radical, the low pressure propagation chain is:

211

212

$$
\mu_{1} \cdot \rightarrow \mathrm{C}_{2} \mathrm{H}_{4}+\mathrm{C}_{6} \mathrm{H}_{13}
$$$$
\mathrm{C}_{6} \mathrm{H}_{13} \cdot \mathrm{C}_{2} \mathrm{H}_{4}+\mathrm{C}_{4} \mathrm{H}_{9} \cdot
$$

$$
\mathrm{C}_{4} \mathrm{H}_{9} \cdot \mathrm{C}_{2} \mathrm{H}_{4}+\mathrm{C}_{2} \mathrm{H}_{5} \cdot
$$

$$
\mathrm{C}_{2} \mathrm{H}_{5} \cdot \mathrm{C}_{8} \mathrm{H}_{18} \rightarrow \mathrm{C}_{2} \mathrm{H}_{6}+\mu^{\cdot}\left(\text { all } \mu_{\mathrm{i}^{\prime}} \text { radicals, including } \mu_{1^{*}}\right. \text { ) }
$$

The corresponding cracking stoichiometric equation is:

$$
\mathrm{C}_{8} \mathrm{H}_{18}=3 \mathrm{C}_{2} \mathrm{H}_{4}+\mathrm{C}_{2} \mathrm{H}_{6}
$$

From $\mu_{2}$ radical, an equivalent propagation chain leads to the stoichiometric equation:

$$
\mathrm{C}_{8} \mathrm{H}_{18}=\mathrm{C}_{3} \mathrm{H}_{6}+2 \mathrm{C}_{2} \mathrm{H}_{4}+\mathrm{CH}_{4}
$$

In the case of $\mu_{3}{ }^{*}$, there are two possibilities of C-C bond scission:

$$
\mu_{3} \cdot \mathrm{C}_{7} \mathrm{H}_{14}+\mathrm{CH}_{3} \cdot
$$

and $\mu_{3}{ }^{\cdot} \rightarrow \mathrm{C}_{4} \mathrm{H}_{8}+\mathrm{C}_{4} \mathrm{H}_{9} \cdot$

These chain reactions lead to the following stoichiometric equations:

$$
\begin{aligned}
& \mathrm{C}_{8} \mathrm{H}_{18}=\mathrm{CH}_{4}+\mathrm{C}_{7} \mathrm{H}_{14} \\
& \mathrm{C}_{8} \mathrm{H}_{18}=\mathrm{C}_{4} \mathrm{H}_{8}+\mathrm{C}_{2} \mathrm{H}_{4}+\mathrm{C}_{2} \mathrm{H}_{6}
\end{aligned}
$$

In the $\mu_{4}$ radical, there are also two possibilities of $\mathrm{C}-\mathrm{C}$ bond scission and the stoichiometric equations are:

$$
\begin{aligned}
& \mathrm{C}_{8} \mathrm{H}_{18}=\mathrm{C}_{6} \mathrm{H}_{12}+\mathrm{C}_{2} \mathrm{H}_{6} \\
& \mathrm{C}_{8} \mathrm{H}_{18}=\mathrm{C}_{5} \mathrm{H}_{10}+\mathrm{C}_{2} \mathrm{H}_{4}+\mathrm{CH}_{4} \quad \text { (IV'a) }
\end{aligned}
$$

So, the stoichiometric equations lead to the formation of two alkanes, $\mathrm{CH}_{4}$ and $\mathrm{C}_{2} \mathrm{H}_{6}$, and all alkenes from $\mathrm{C}_{2}$ to $\mathrm{C}_{7}$. This well agrees with the main products observed when the pyrolysis of $n$-octane is performed at very low reactant concentration.

If we suppose, in a first approximation, that all the cracking stoichiometric equations have the same rate, the global stoichiometric equation is:

$$
6 \mathrm{C}_{8} \mathrm{H}_{18}=7 \mathrm{C}_{2} \mathrm{H}_{4}+3 \mathrm{CH}_{4}+3 \mathrm{C}_{2} \mathrm{H}_{6}+\mathrm{C}_{3} \mathrm{H}_{6}+\mathrm{C}_{4} \mathrm{H}_{8}+\mathrm{C}_{5} \mathrm{H}_{10}+\mathrm{C}_{6} \mathrm{H}_{12}+\mathrm{C}_{7} \mathrm{H}_{14}
$$


That leads to the following classification:

$$
\mathrm{C}_{2} \mathrm{H}_{4}>\mathrm{CH}_{4}=\mathrm{C}_{2} \mathrm{H}_{6}>\mathrm{C}_{3} \mathrm{H}_{6}=\mathrm{C}_{4} \mathrm{H}_{8}=\mathrm{C}_{5} \mathrm{H}_{10}=\mathrm{C}_{6} \mathrm{H}_{12}=\mathrm{C}_{7} \mathrm{H}_{14} \quad \text { (without alkanes in } \mathrm{C}_{3+} \text { ) }
$$

The classification has to be compared with our experimental results at $450^{\circ} \mathrm{C}$ and $4 \mathrm{~h}$ (Figures 5

238 and 6):

$\mathrm{C}_{2} \mathrm{H}_{4}>\mathrm{CH}_{4} \approx \mathrm{C}_{3} \mathrm{H}_{6}>\mathrm{C}_{4} \mathrm{H}_{8}>\mathrm{C}_{5} \mathrm{H}_{10} \approx \mathrm{C}_{6} \mathrm{H}_{12}>\mathrm{C}_{2} \mathrm{H}_{6}>\mathrm{C}_{7} \mathrm{H}_{14}>>\mathrm{C}_{3} \mathrm{H}_{8}, \mathrm{C}_{4} \mathrm{H}_{10}, \mathrm{C}_{5} \mathrm{H}_{12}, \mathrm{C}_{6} \mathrm{H}_{14}$ and

$240 \quad \mathrm{C}_{7} \mathrm{H}_{16}$

241 The little quantitative differences between the experimental classification and the classification

242 obtained by the stoichiometric equations could be explained by three approximations. First, the concentrations of the $\mu_{\mathrm{i}}$ are not equal, because $\mu_{1} \cdot$ is a primary radical which is less stable than a

244 secondary one:

$$
\left[\mu_{1} \cdot\right]<\left[\mu_{2} \cdot\right] \sim\left[\mu_{3^{\cdot}}\right] \sim\left[\mu_{4^{*}}\right]
$$

Consequently, the stoichiometric equation I' (leading to $\mathrm{C}_{2} \mathrm{H}_{6}$ ) is overestimated in the argument which only considers the stoichiometric equations.

Another correction is that the decompositions by $\beta$-scission of $\mathrm{C}-\mathrm{H}$ bonds are not completely negligible at $450^{\circ} \mathrm{C}$. They lead to the conversion of ethane into ethylene, which is the major 250 product:

$$
\mathrm{C}_{2} \mathrm{H}_{5} \cdot \mathrm{C}_{2} \mathrm{H}_{4}+\mathrm{H}^{\cdot}
$$

$$
\mathrm{H}^{\cdot}+\mathrm{C}_{8} \mathrm{H}_{18} \rightarrow \mathrm{H}_{2}+\mu
$$

Finally, the formation of $\mathrm{C}_{3}{ }^{+}$alkanes in very low quantities indicates that the $\mathrm{H}$ transfer reactions of $\beta$ radicals $\left(\mathrm{C}_{3}-\mathrm{C}_{6}\right.$ radicals $)$ are not totally negligible and produce $\mathrm{C}_{3}{ }^{+}$alkanes:

$$
\beta \cdot \mu \mathrm{H} \rightarrow \mathrm{C}_{3+} \text { alkanes }+\mu \cdot
$$

This brief kinetic interpretation well explains the chemistry observed for the $n$-octane pyrolysis at low reactant concentration and low temperature, and the differences in the product distribution obtained at high concentration and pressure (competition: unimolecular versus bimolecular reactions). 


\section{Modeling of $\boldsymbol{n}$-octane thermal decomposition at very low reactant concentration.}

262 On the basis of these free-radical reactions, a systematic approach is used to build a detailed mechanism of $n$-octane pyrolysis at low reactant concentration and low temperature. Using EXGAS software [40, 51], the mechanism (primary and partial secondary) is made of 184 reactions involving 34 species (16 molecules and 18 radicals). The kinetic data originate from NIST Database [52] or literature and are summarized in [40]. The simulations are performed using Chemkin II software [53], in a closed isochoric and isothermal reactor (Senkin).

The comparison between the experimental results and simulation ones led to the adjustment of some rate constants by a minor factor (less or equal to 10) in order to better account for main pyrolysis products. Figures 5, 6 and 7 present the comparison between the experimental data and the simulation results of the molar fractions ( $n$-octane and reaction products) versus time ( 1 to 240 minutes) at $450^{\circ} \mathrm{C}$ and 1 mbar of $n$-octane partial pressure (total pressure 1500 mbar - molar 273 fraction $0.07 \%)$.

274 The detailed kinetic model accounts for the nature of the products observed as well as for their amounts, at least semi-quantitatively. The evolution of alkenes, $n$-octane and propane is well simulated by the kinetic model, although ethene is very slightly over-estimated, and pentene and 277 hexene are under-estimated, but they are minor products. The overestimation of ethene can be 278 due to additions of some radicals to alkenes, which are secondary reactions not taken into account by the model. Methane and ethane are also very slightly overestimated by the model, probably for the same reason, because methyl and ethyl radicals are the predominant radicals. In

281 the case of ethane, this may also be due to the decomposition of $\mathrm{C}-\mathrm{H}$ bonds, which is not 282 completely negligible at $450^{\circ} \mathrm{C}$ and leads to the conversion of ethane into ethylene. Nevertheless 283 we can therefore conclude that the kinetic model is globally validated as well as the kinetic 284 scheme proposed to explain the chemistry observed at very low concentration.

285 By simulation of the kinetic model, the chain length can be estimated by the ratio of the global 286 propagation rate to the initiation rate. The main $\mathrm{H}$-transfers with $n$-octane are those implying the 
methyl and ethyl radicals. The chain length is equal to 120 at $450^{\circ} \mathrm{C}$ and low $n$-octane 288 concentration (molar fraction 0.07\%). The chain length increases when the temperature 289 decreases and in our conditions, the chain length is always very high.

290 When a reaction follows a first order kinetic law, the plot of log (1-conversion) versus time must 291 give a linear relationship and the slope corresponds to the rate constant. Assuming a first order 292 kinetics, we can estimate the apparent activation energy of $n$-octane pyrolysis: it is close to 218 $293 \mathrm{~kJ} / \mathrm{mol}$ and the frequency factor is about $3.63 \times 10^{10}\left(\mathrm{~s}^{-1}\right)$, in the range $350^{\circ} \mathrm{C}-450^{\circ} \mathrm{C}$ and $1 \mathrm{mbar}$ 294 of $n$-octane partial pressure. This apparent activation energy is lower than that of alkane 295 pyrolysis at the same temperatures but at high pressure (100-700 bar), which is close to 284-289 $\mathrm{kJ} / \mathrm{mol}[35,39,42,54]$.

This difference can be explained by the concentration of reactant that is totally different in our 298 case in comparison to those applied in $[35,39,42]$. The elementary reactions that are important, are also different, depending on the reaction conditions. Indeed, in the chain propagation, the $\mathrm{H}$ transfers of radicals with reactant, which produce smaller alkanes than the reactant, are in competition with the decomposition of this radical by $\beta$-scission which produce smaller alkenes:

$$
\begin{array}{lll}
\beta \cdot & \rightarrow & \text { alkene }+\beta^{\prime} \\
\beta \cdot+\mu \mathrm{H} & \rightarrow & \text { alkane } \boldsymbol{\beta H}+\mu
\end{array}
$$

304 At very low reactant concentration, unimolecular decomposition reactions are greatly favored over bimolecular reactions, and that leads to very different apparent activation energies.

\section{Conclusion}

308 An experimental study of the pyrolysis of $n$-octane has been performed at very low reactant 309 concentration ( 1 mbar diluted in inert gas - total pressure 1500 mbar - molar fraction $0.07 \%$ ) in a 310 closed reactor, at temperatures between $350^{\circ} \mathrm{C}$ and $450^{\circ} \mathrm{C}$ and reaction time from $1 \mathrm{~h}$ to $70 \mathrm{~h}$.

311 The major products of the reaction are 1-alkenes $\left(\mathrm{C}_{2} \mathrm{H}_{4}\right.$ to $\left.\mathrm{C}_{7} \mathrm{H}_{14}\right)$, methane and ethane. These 312 experimental results are different from the thermal decomposition of $n$-octane at the same low 
313 temperature but at high pressure (the major products are only alkanes at 700 bar).

314 Indeed, at very low reactant concentration, unimolecular decomposition reactions are greatly

315 favored over bimolecular reactions. In our low concentration conditions, radicals decompose 316 several times by $\beta$-scission of $\mathrm{C}-\mathrm{C}$ bonds as much as possible (unimolecular reaction), rather

317 than react by H-transfer with the reactant (bimolecular reaction) which produces an alkane. The 318 methyl and ethyl radicals cannot decompose by C-C $\beta$-scission, and so they react by H-transfer 319 with the reactant and produce methane or ethane and $\mu$, which is the chain carrier radical.

321 On the basis of these free-radical reactions, a detailed kinetic model (184 reactions, 16 molecules 322 and 18 radicals) is proposed, which allows a satisfying description of the experimental results:

$323-$ the nature of the principal reaction products is correct,

$324-\mathrm{C}_{2} \mathrm{H}_{4}$ is the most important product,

- $\mathrm{CH}_{4}$ and $\mathrm{C}_{2} \mathrm{H}_{6}$ are the only two important alkanes,

- the alkenes from $\mathrm{C}_{3}$ to $\mathrm{C}_{7}$ are formed in rather close quantities,

- the $\mathrm{C}_{3}{ }^{+}$alkanes are very minor products.

328 These results of $n$-octane pyrolysis obtained at very low reactant concentration underline the

329 crucial role of concentration and partial pressure in the reaction pathways and products of the

330 alkane pyrolysis. They clearly demonstrate that results obtained at low partial pressure cannot be extrapolated at high pressure and vice versa. 


\section{REFERENCES}

336 [1] M. Vandenbroucke, F.Behar, J.L. Rudkiewicz, Kinetic modelling of petroleum formation and

cracking: implications from the high pressure/high temperature Elgin Field (UK, North Sea),

Org. Geochem. 30 (9) (1999) 1105-1125.

[2] K.E. Peters, M.G. Fowler, Applications of petroleum geochemistry to exploration and 340 reservoir management, Org. Geochem. 33 (1) (2002) 5-36.

341 [3] R.J. Hill, Y. Tang, I.R. Kaplan, Insights into oil cracking based on laboratory experiments, 342 Org. Geochem. 34 (12) (2003) 1651-1672.

343 [4] M. Bajus, V.C. Vesela, P.A. Leclercq, J.A. Rijks, Steam Cracking of Hydrocarbons. 2. 344 Pyrolysis of Methylcyclohexane, Ind. Eng. Chem. Prod. Res. Dev 18 (1) (1979) 135-142.

345 [5] G.F. Froment, Kinetics and reactor design in the thermal cracking for olefins production, 346 Chem. Eng. Sci. 47 (9-11) (1992) 2163-2177.

347 [6] S.M. Sadrameli, A.E.S. Green, Systematics and modeling representations of naphtha thermal 348 cracking for olefin production, J. Anal. Appl. Pyrolysis, 73 (2) (2005) 305-313.

349 [7] K. M. Van Geem, D. Hudebine, M.F. Reyniers, F.Wahl, J. Verstraete, G. B. Marin, 350 Molecular reconstruction of naphtha steam cracking feedstocks based on commercial indices, 351 Comput. Chem. Eng., 31 (9) (2007) 1020-1034.

352 [8] T. Edwards, Cracking and deposition behavior of supercritical hydrocarbon aviation fuels, 353 Combust. Sci. Tech., 178 (1-3) (2006) 307-334.

354 [9] O. Herbinet, B. Sirjean, R. Bounaceur, R. Fournet, F. Battin-Leclerc, G. Scacchi, P.M. 355 Marquaire, Primary reactions of the thermal decomposition of tricyclodecane, J. Phys. Chem. A, $356110(39)(2006)$ 11298-11314.

357 [10] N. Vandewiele, G. Magoon, K. Van Geem, M.F. Reyniers, W. Green, G. Marin, Kinetic 358 Modeling of Jet Propellant-10 Pyrolysis, Energy Fuels, 29 (1) (2015) 413-427.

359 [11] P.R. Solomon, M.A. Serio, G.V., Despande, E. Kroo, Cross-linking reactions during coal 
conversion, Energy Fuels 4 (1) (1990) 42-54.

361 [12] S. Wang, H. Huang, K. Wang, M.T. Klein, W.H. Calkins, Kinetics of Coal Liquefaction

Distillation Resid Conversion, Energy Fuels, 12 (6) (1998) 1335-1341.

[13] N. Howaniec, A. Smoliński, Effect of fuel blend composition on the efficiency of hydrogen-

364 rich gas production in co-gasification of coal and biomass, Fuel 128 (2014) 442-450.

365 [14] J.G. Speight, Coal gasification processes for synthetic liquid fuel production, in: R. Luque,

366 J. Speight (Eds.), Gasification for Synthetic Fuel Production - Fundamentals, Processes and 367 Applications, Woodhead Publishing Series in Energy, Elsevier Ltd, 2015.

368 [15] W. Kaminsky, B. Schlesselmann, C. Simon, Olefins from polyolefins and mixed plastics by 369 pyrolysis, J. Anal. Appl. Pyrol. 32 (1995) 19-27.

370 [16] A. Uddin, K. Koizumi, K. Murata, Y. Sakata, Thermal and catalytic degradation of 371 structurally different types of polyethylene into fuel oil, Polym. Degrad. Stab. 56 (1) (1997) 37372 44.

373 [17] E. Hajekova, M. Bajus, Recycling of low-density polyethylene and polypropylene via 374 copyrolysis of polyalkene oil/waxes with naphtha: product distribution and coke formation, J. 375 Anal. Appl. Pyrolysis 74 (1-2) (2005) 270-281.

376 [18] I. Ziegler, R. Fournet, P.M.Marquaire, Pyrolysis of propane for CVI of pyrocarbon - part I: 377 Experimental and modeling study of the formation of toluene and aliphatic species, J. Anal. 378 Appl. Pyrol. 73(2) (2005) 212-230.

379 [19] I. Ziegler, R. Fournet, P.M. Marquaire, Pyrolysis of propane for CVI of pyrocarbon - part II: 380 Experimental and modeling study of polyaromatic species, J. Anal. Appl. Pyrol. 73(2) (2005) $381 \quad 231-247$.

382 [20] R. Lacroix, R. Fournet, I. Ziegler-Devin, P.M. Marquaire, Kinetic Modeling of Surface 383 Reactions Involved in CVI of Pyrocarbon obtained by propane pyrolysis, Carbon 48 (1) 384 (2010)132-144.

385 [21] S. Moldoveanu, Pyrolysis of organic molecules-Applications to Health and Environmental 
Issues, first ed., Elsevier, 2009.

387 [22] P.E. Savage, Mechanisms and kinetics models for hydrocarbon pyrolysis, J. Anal. Appl. 388 Pyrolysis 54 (1-2) (2000) 109-126.

389 [23] K.J. Laidler, L.F Louks, Comprehensive Chemical Kinetics, vol 5, Elsevier, 1972.

390 [24] M.L. Poutsma, Fundamental reactions of free radicals relevant to pyrolysis reactions, J. 391 Anal. Appl. Pyrolysis 54 (1-2) (2000) 5-35.

392 [25] F. O. Rice, K. F. Herzfeld, The Thermal Decomposition of Organic Compounds from the 393 Standpoint of Free Radicals. VI. The Mechanism of Some Chain Reactions, J. Am. Chem. Soc., $39456(1934) 284-289$.

395 [26] D.L.Allara, R. Shaw, A compilation ok kinetic-parameters for the thermal degradation of 396 normal-alkane molecules, J. Phys. Chem. Ref. Data, 9 (3) (1980) 523-559.

397 [27] T. J. Ford, Liquid-Phase Thermal Decomposition of Hexadecane: Reaction Mechanisms, 398 Ind. Eng. Chem. Fundam., 25 (2) (1986) 240-243.

399 [28] F. Dominé, Kinetics of hexane pyrolysis at very high pressures. 1. Experimental study, 400 Energy Fuels 3 (1) (1989) 89-96.

401 [29] F. Dominé, P.M. Marquaire, C. Muller, G.-M. Côme, Kinetics of hexane pyrolysis at very 402 high pressures. 2. Computer modeling, Energy Fuels 4(1) (1990) 2-10.

403 [30] F. Khorasheh, M. R. Gray, High-Pressure Thermal Cracking of $n$-Hexadecane, Ind. Eng. 404 Chem. Res., 32 (9) (1993) 1853-1863.

405 [31] K.J. Jackson, A.K. Burnham, R.L. Braun, K.G. Knauss, Temperature and pressure 406 dependence of n-hexadecane cracking, Org. Geochem. 23 (10) (1995) 941-953.

407 [32] O. Herbinet, PM. Marquaire, F. Battin-Leclerc, R. Fournet, Thermal stability of $n$-dodecane: 408 experiments and kinetic modeling, J. Anal. Appl. Pyrol., 78(2) (2007) 419-429.

409 [33] M. J. De Witt, D. J. Dooling, L J. Broadbelt, Computer Generation of Reaction Mechanisms 410 Using Quantitative Rate Information: Application to Long-Chain Hydrocarbon Pyrolysis, Ind. 411 Eng. Chem. Res. 39 (2000) 2228-2237. 
[34] J. Yu, S. Eser, Kinetics of Supercritical-Phase Thermal Decomposition of C10-C14 Normal 413 Alkanes and Their Mixtures Ind. Eng. Chem. Res. 36 (3) (1997) 585-591.

414 [35] F. Behar, M. Vandenbroucke, Experimental Determination of the Rate Constants of the $n$ 415 C25 Thermal Cracking at 120, 400, and 800 bar: Implications for High-Pressure/High416 Temperature Prospects, Energy Fuels 10 (4) (1996) 932-940.

417 [36] R. Bounaceur, G. Scacchi, P.M. Marquaire, F. Dominé, D. Dessort, B. Pradier, Inhibiting 418 effect of tetralin on the pyrolytic decomposition of hexadecane. Comparison with toluene, Ind. 419 Eng. Chem. Res. 41 (19) (2002) 4689-4701.

420 [37] V. Burklé-Vitzthum, R. Michels, G. Scacchi, P.M. Marquaire, D. Dessort, B. Pradier, O. 421 Brevart, Kinetic effect of alkylaromatics on the thermal stability of hydrocarbons under 422 geological conditions, Org. Geochem. 35 (1) (2004) 3-31.

423 [38] V. Burklé-Vitzthum, R. Michels, R. Bounaceur, P.M. Marquaire, G. Scacchi, Experimental 424 study and modeling of the role of hydronaphthalenics on the thermal stability of hydrocarbons at 425 laboratory and geological conditions, Ind. Eng. Chem. Res. 44 (24) (2005) 8972-8987.

426 [39] F. Lannuzel, R. Bounaceur, R. Michels, G. Scacchi, P.M. Marquaire, Reassessment of the 427 kinetic influence of toluene on $n$-alkanes pyrolysis, Energy Fuels 24 (7) (2010) 3817-3830.

428 [40] R. Bounaceur, V. Warth, P. M. Marquaire, G. Scacchi, F. Dominé, D. Dessort, B. Pradier, 429 O. Brevart, Modeling of hydrocarbons pyrolysis at low temperature. Automatic generation of 430 free radicals mechanisms, J. Anal. Appl. Pyrolysis 64 (2002) 103-122.

431 [41] F. Dominé, R. Bounaceur, G. Scacchi, P.M. Marquaire, D. Dessort, B. Pradier, O. Brévart, 432 Up to what temperature is petroleum stable ? New insights from a 5200 free radical reactions 433 model, Org. Geochem. 33 (12) (2002) 1487-1499.

434 [42] V. Burklé-Vitzthum, R. Bounaceur, P-M. Marquaire, F. Montel, L. Fusetti, Thermal 435 evolution of $n$ - and iso-alkanes in oils - Part 1: Pyrolysis model for a mixture of 78 alkanes (C1436 C32) including 13,206 free radical reactions, Org. Geochem. 42 (5) (2011) 439-450.

437 [43] I. Ziegler-Devin, R. Bounaceur, C. Perrin, R. Wörner, F. Patisson, P. M. Marquaire, Kinetic 
study of abatement of low concentration of dibenzofuran by oxidation - Effects of co-reactants, Chem. Eng. J. 218 (2013) 154-163.

[44] A. Tritz, I. Ziegler-Devin, C. Perrin, P.M. Marquaire, Experimental study of the oxidation and pyrolysis of dibenzofuran at very low concentration, J. Env. Chem. Eng., 2 (2014) 143-153. [45] G. Vignoles, F. Langlais, C. Descamps, A. Mouchon, H. Le Poche H, N. Reuge, CVD and CVI of pyrocarbon from various precursors, Surf. Coat. Technol. 188-189 (2004) 241-249.

[46] K. Norinaga, O. Deutschmann, Detailed kinetic modeling of gas-phase reactions in the chemical vapor deposit of carbon from light hydrocarbons, Ind. Eng. Chem. Res. 46 (11) (2007) 3547-3557.

[47] M. Frenklach, H. Wang, Detailed surface and gas-phase chemical kinetics of diamond deposit, Phys. Rev. B: Condens. Matter, 43 (2) (1991) 1520-1545.

[48] S.W. Benson, G. N. Spokes, Very Low Pressure Pyrolysis. III t-butyl hydroperoxide in Fused Silica and Stainless Steel Reactors, J. Phys. Chem. 72 (1968)1182-1186.

[49] R. Atkinson, J. Arey, S. M. Aschmann Atmospheric chemistry of alkanes: Review and recent developments Atmospheric Environment, 42 (2008) 5859-5871

[50] O. Venot, E. Hébrard, M. Agúndez, L. Decin, R. Bounaceur A new chemical scheme to study carbon-rich exoplanet atmospheres Astronomy \& Astrophysics, in press 2015 (arXiv:1502.03567)

[51] F. Battin-Leclerc, J. Biet, R. Bounaceur, G.M. Côme, R. Fournet, P.-A. Glaude, X. Grandmougin, O. Herbinet, G. Scacchi, V. Warth, EXGAS-ALKANES-ESTERS: A software for the automatic generation of mechanisms for the oxidation of alkanes and esters, (2010) LRGP, UPR CNRS 3349

[52] J. A. Manion, R. E. Huie, R. D. Levin, D. R. Burgess Jr., V. L. Orkin, W. Tsang, W. S. McGivern, J. W. Hudgens, V. D. Knyazev, D. B. Atkinson, E. Chai, A. M. Tereza, C.-Y. Lin, T. C. Allison, W. G. Mallard, F. Westley, J. T. Herron, R. F. Hampson, D. H. Frizzell, NIST Chemical Kinetics Database, NIST Standard Reference Database 17, Version 7.0 (Web Version), 
464 Release 1.4.3, Data version 2008.12, National Institute of Standards and Technology, 465 Gaithersburg, Maryland, 20899-8320. http://kinetics.nist.gov

466 [53] R.J Kee, F.M. Rupley, J.A. Miller, Chemkin-II: A Fortran chemical kinetics package for the 467 analysis of gas-phase chemical kinetics, (1989) Sandia National Laboratories, Livermore, CA.

468 [54] F. Behar, F. Lorant, L. Mazeas, Elaboration of a new compositional kinetic schema for oil 469 cracking, Org. Geochem. 39 (6) (2008) 764-782.

470

471

472

473 
476 Table 1: Product distribution in mol. $\%$ - Octane pyrolysis at $450^{\circ} \mathrm{C}$-initial pressure of octane $=$ 4771 mbar - total pressure $=1500 \mathrm{mbar}$

478

\begin{tabular}{|llllll|}
\hline & & & & \\
\hline $\mathbf{C H}_{4}$ & - & $9.40 \times 10^{-4}$ & $1.39 \times 10^{-3}$ & $1.87 \times 10^{-3}$ & $2.25 \times 10^{-3}$ \\
\hline $\mathbf{C}_{2} \mathbf{H}_{6}$ & - & $2.40 \times 10^{-4}$ & $3.21 \times 10^{-4}$ & $4.06 \times 10^{-4}$ & $5.32 \times 10^{-4}$ \\
\hline $\mathbf{C}_{3} \mathbf{H}_{8}$ & - & $8.07 \times 10^{-6}$ & $1.01 \times 10^{-5}$ & $9.46 \times 10^{-6}$ & $1.31 \times 10^{-5}$ \\
\hline $\mathbf{C}_{4} \mathbf{H}_{10}$ & - & $3.23 \times 10^{-6}$ & $4.90 \times 10^{-6}$ & $4.71 \times 10^{-6}$ & $5.27 \times 10^{-6}$ \\
\hline $\mathbf{C}_{2} \mathbf{H}_{4}$ & - & $3.28 \times 10^{-3}$ & $4.79 \times 10^{-3}$ & $6.31 \times 10^{-3}$ & $7.56 \times 10^{-3}$ \\
\hline $\mathbf{C}_{3} \mathbf{H}_{6}$ & - & $1.32 \times 10^{-3}$ & $1.94 \times 10^{-3}$ & $2.65 \times 10^{-3}$ & $3.22 \times 10^{-3}$ \\
\hline $\mathbf{C}_{4} \mathbf{H}_{8}$ & - & $6.56 \times 10^{-4}$ & $8.85 \times 10^{-4}$ & $1.16 \times 10^{-3}$ & $1.40 \times 10^{-3}$ \\
\hline $\mathbf{C}_{5} \mathbf{H}_{10}$ & - & $5.18 \times 10^{-4}$ & $7.50 \times 10^{-4}$ & $8.74 \times 10^{-4}$ & $9.61 \times 10^{-4}$ \\
\hline $\mathbf{C}_{6} \mathbf{H}_{12}$ & - & $4.94 \times 10^{-4}$ & $6.43 \times 10^{-4}$ & $7.50 \times 10^{-4}$ & $8.60 \times 10^{-4}$ \\
\hline $\mathbf{C}_{7} \mathbf{H}_{14}$ & - & $1.02 \times 10^{-4}$ & $1.43 \times 10^{-4}$ & $2.16 \times 10^{-4}$ & $2.02 \times 10^{-4}$ \\
\hline $\mathbf{C}_{8} \mathbf{H}_{18}$ & $6.65 \times 10^{-2}$ & $6.49 \times 10^{-2}$ & $6.31 \times 10^{-2}$ & $6.21 \times 10^{-2}$ & $6.11 \times 10^{-2}$ \\
\hline
\end{tabular}


<smiles></smiles>

483

484

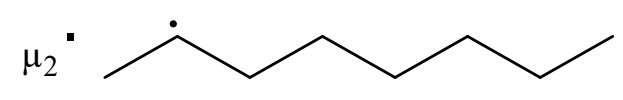

485<smiles>CCCCCCCC</smiles>

486

487<smiles>CCCCCCCC[18OH]</smiles>

Figure 1. The $\mu_{\mathrm{i}}$ radicals of $n$-octane. Names used in the equations of reactions.

489
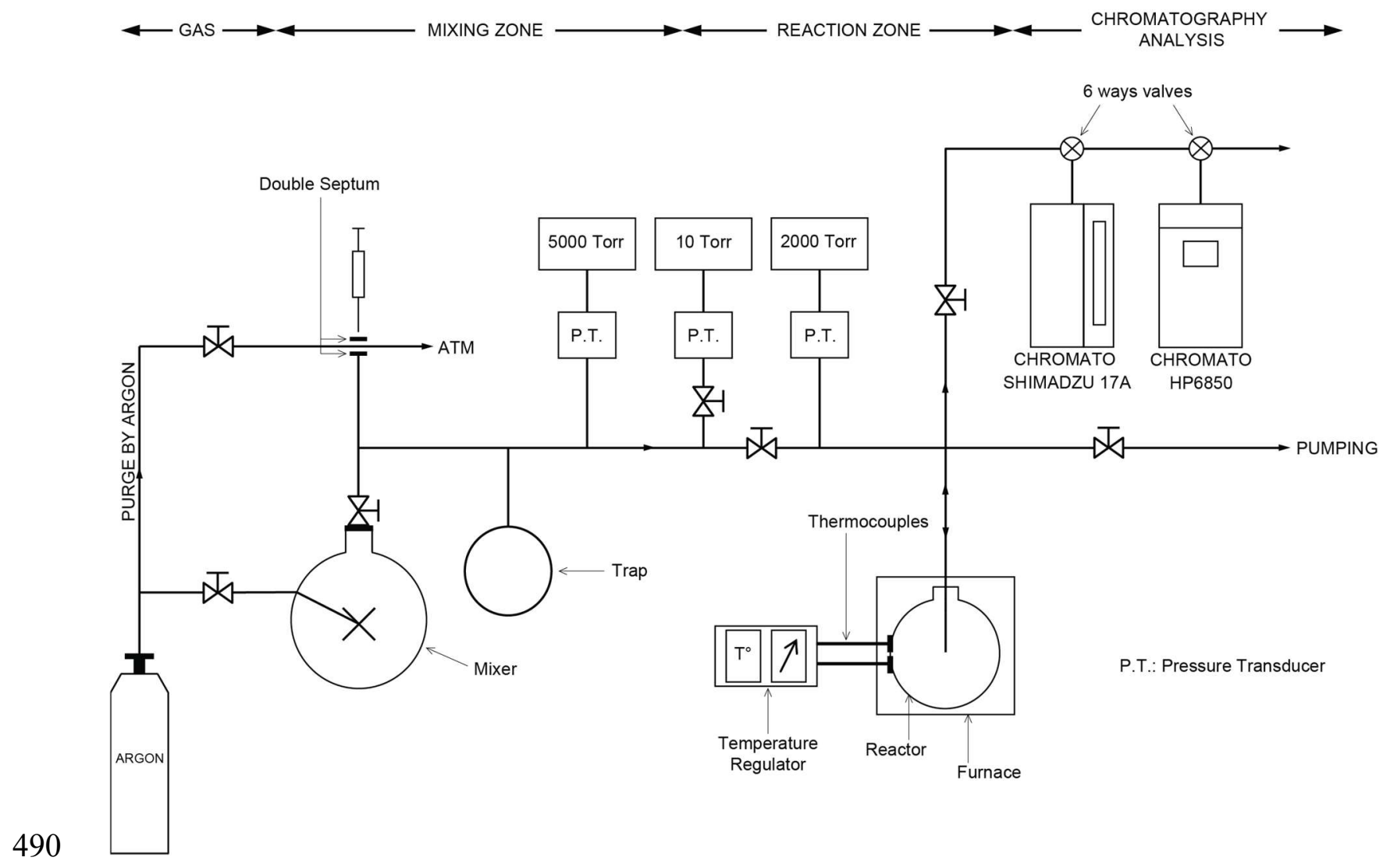

494 Figure 2. Flow sheet of the experimental setup. 


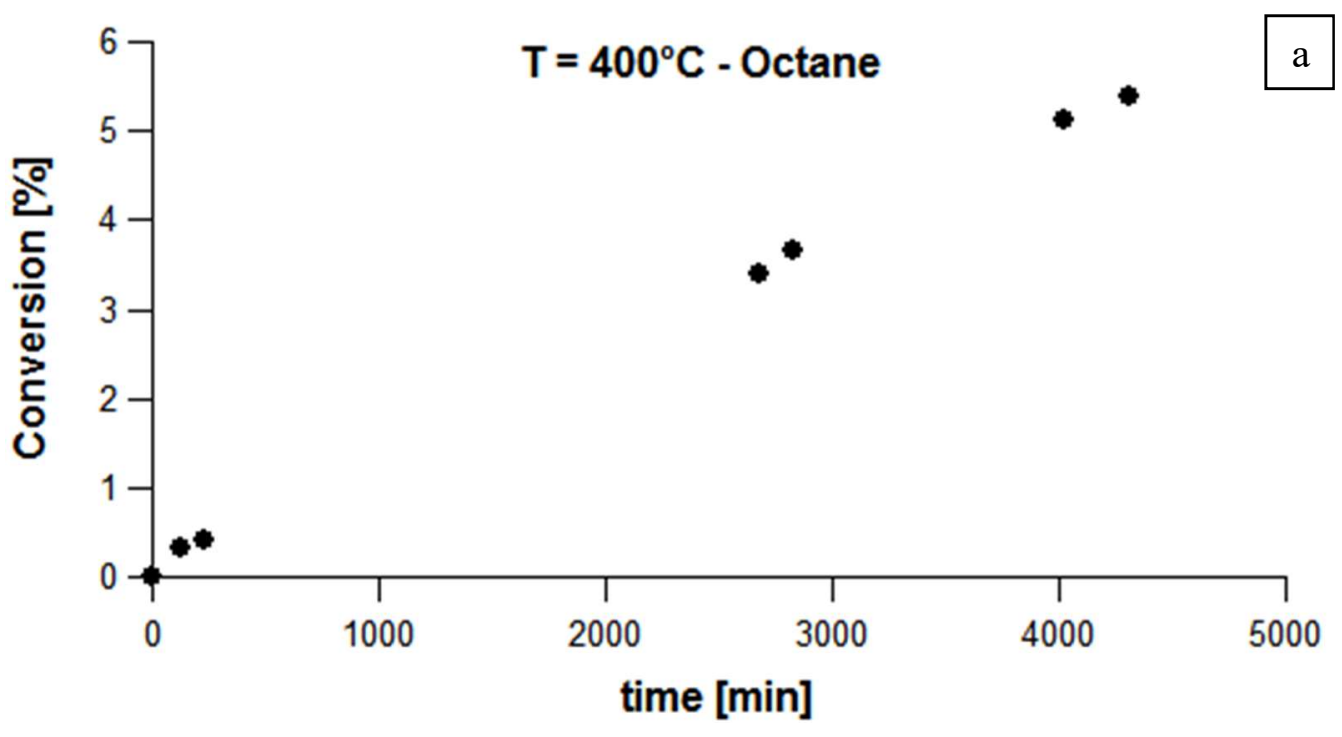

496

497

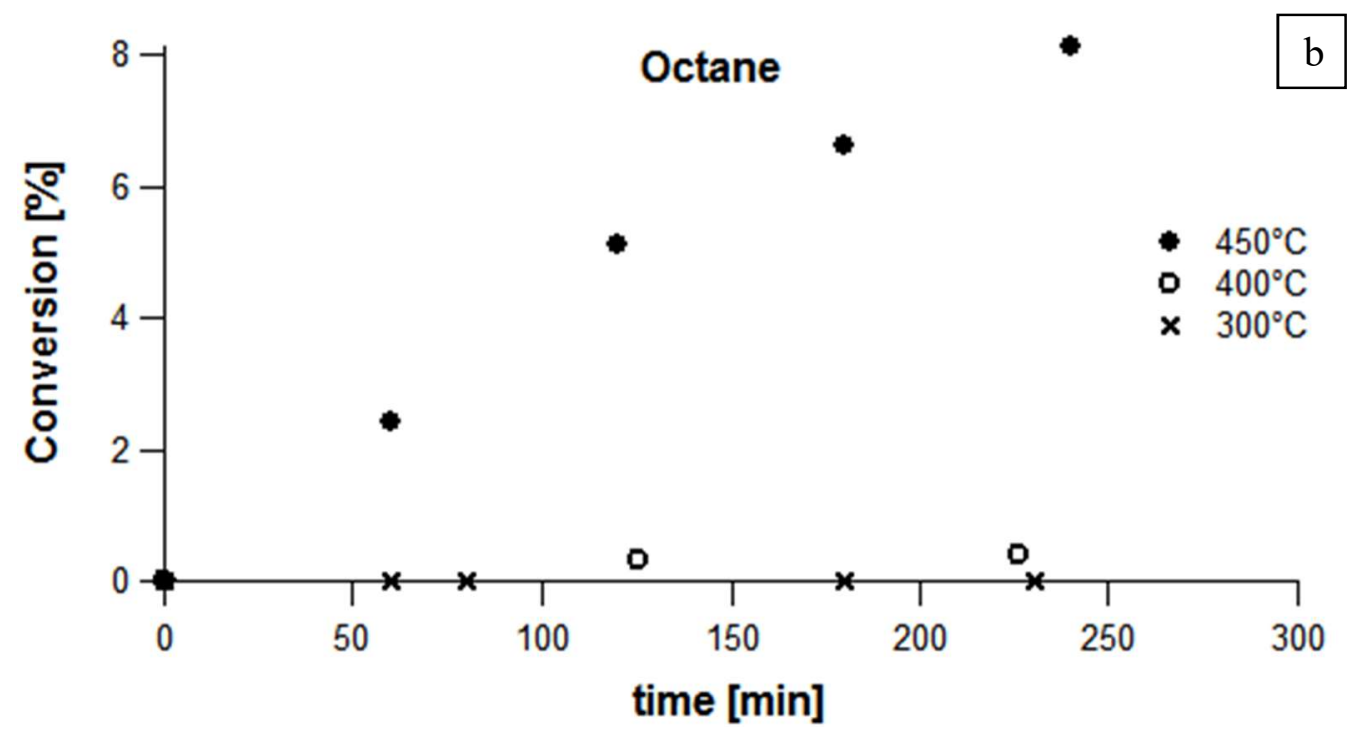

499

500

501 Figures 3. Evolution of $n$-octane conversion as a function of time, a) at $400^{\circ} \mathrm{C}$, up to $4300 \mathrm{~min}$, 502 and b) at $350,400,450^{\circ} \mathrm{C}$, up to $240 \mathrm{~min}$ ( $1 \mathrm{mbar}$ initial $n$-octane pressure).

503

504

505

506 


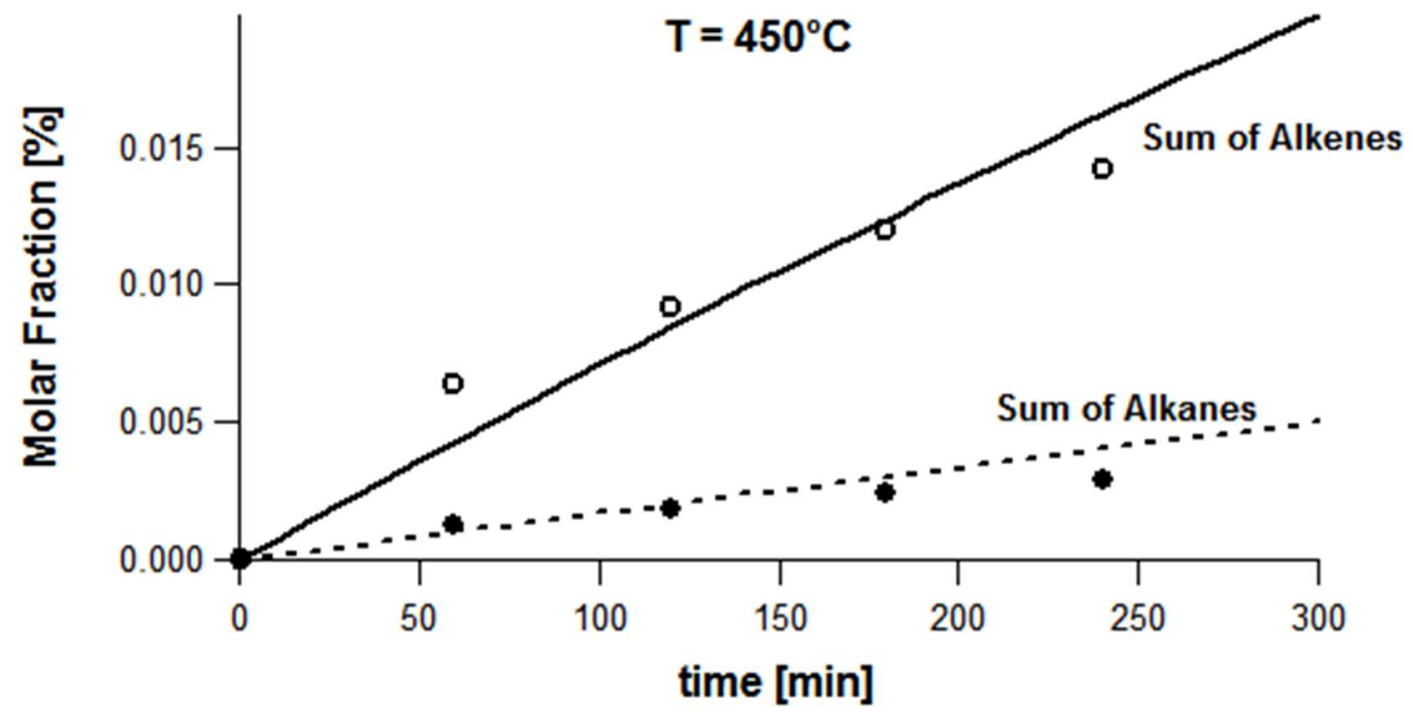

509

510 Figure 4. Comparison between experimental (dots) and simulation (solid lines) molar fractions

511 of the alkanes-minus and alkenes, as a function of time, at $450^{\circ} \mathrm{C}$ and $1 \mathrm{mbar}$ initial $n$-octane 512 pressure.

513 


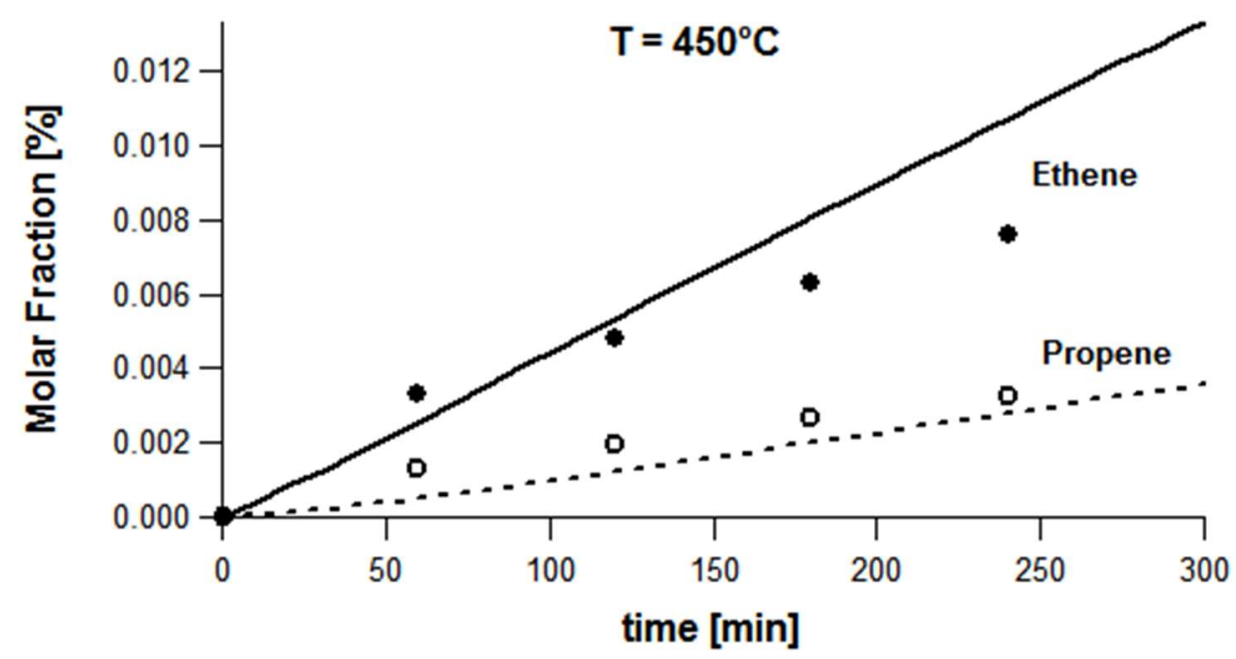

514

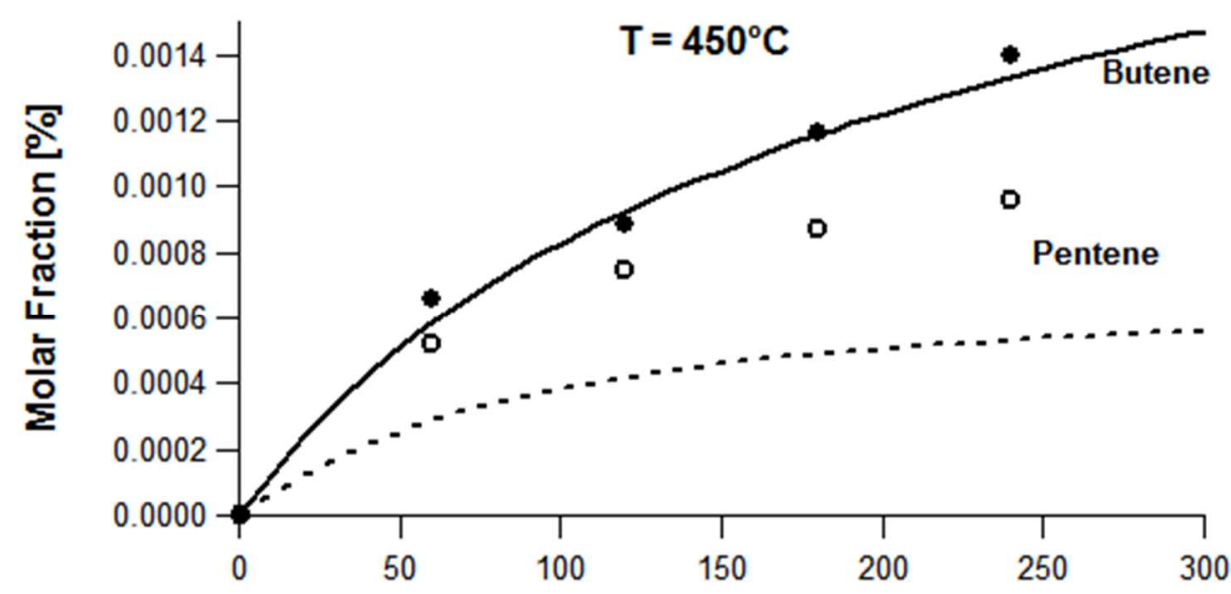

515

time [min]

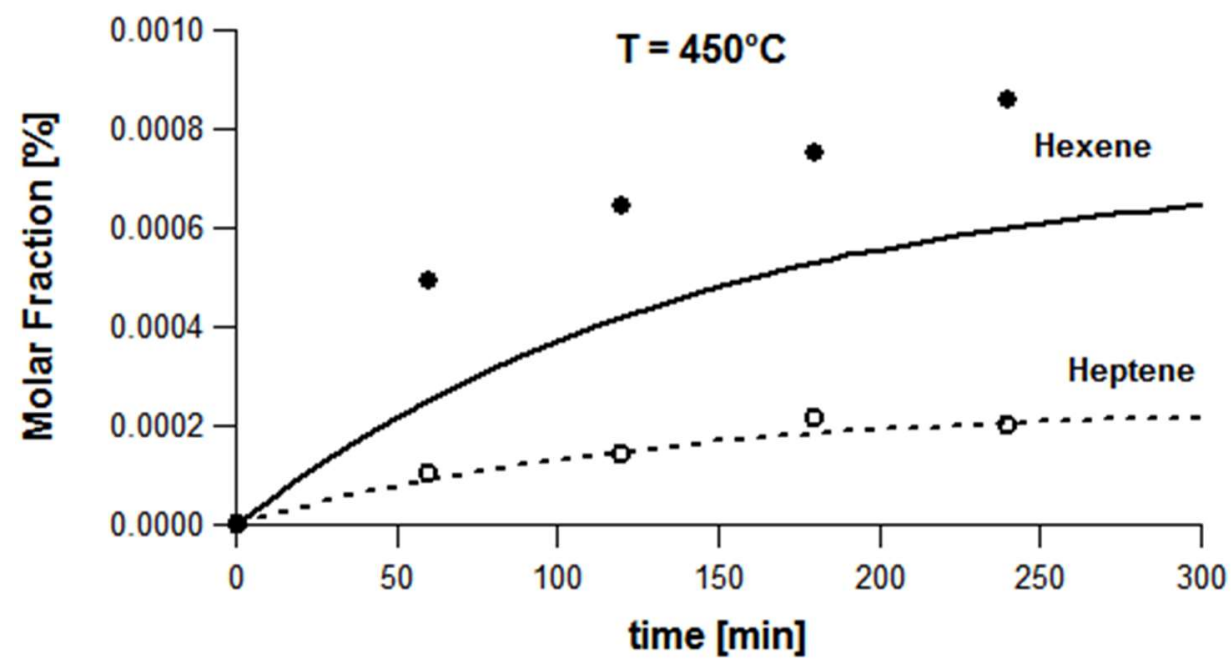

519 Figures 5. Comparison between experimental (dots) and simulation (solid lines) molar fractions

520 of the alkenes (from ethylene to heptene), as a function of time, at $450^{\circ} \mathrm{C}$ and $1 \mathrm{mbar}$ initial $n$ -

521 octane pressure. 


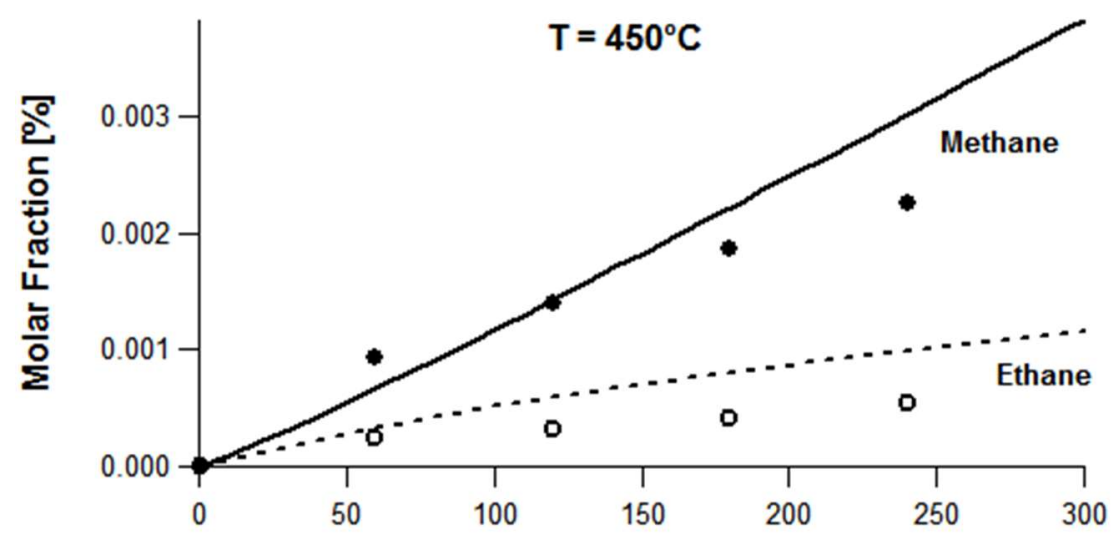

524

\section{time [min]}

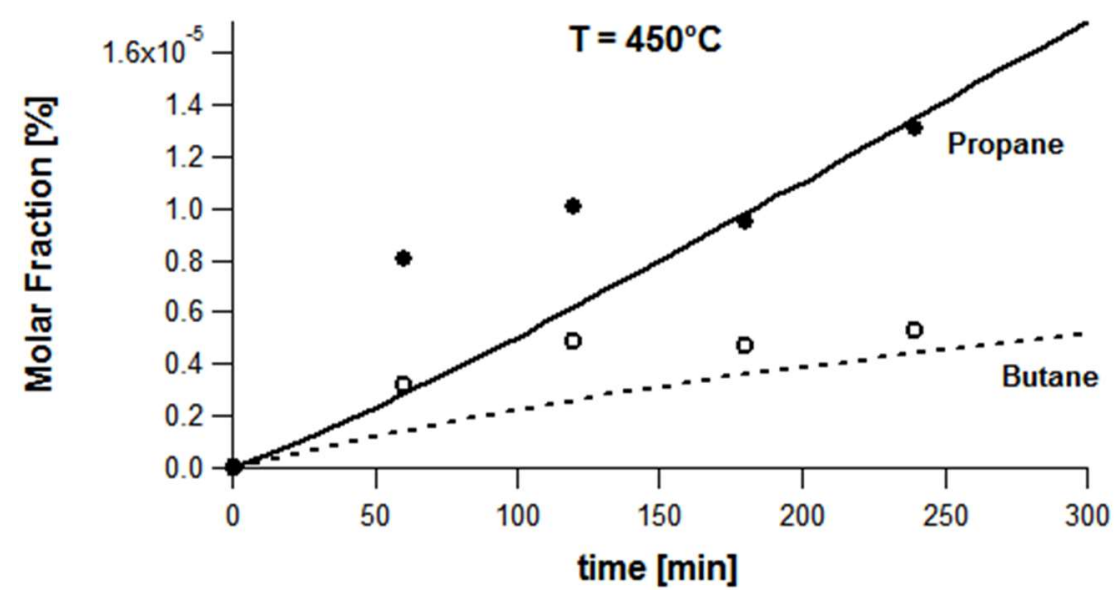

527 Figures 6. Comparison between experimental (dots) and simulation (solid lines) molar fractions 528 of the alkanes (from methane to butane), as a function of time, at $450^{\circ} \mathrm{C}$ and $1 \mathrm{mbar}$ initial $n$ 529 octane pressure.

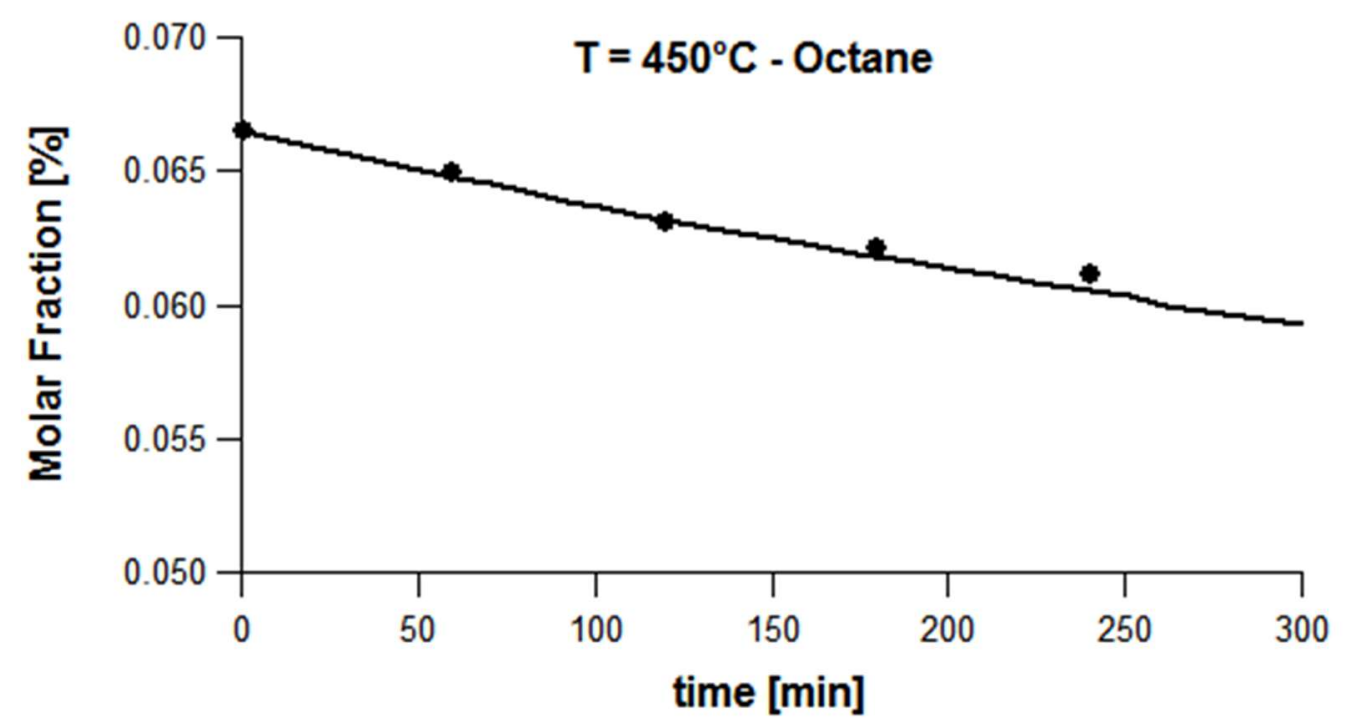


534 Figure 7. Comparison between experimental and simulation molar fraction of $n$-octane, as a 535 function of time, at $450^{\circ} \mathrm{C}$ and $1 \mathrm{mbar}$ initial $n$-octane pressure.

536

537 